Int. J. Dev. Biol. 63: 579-587 (2019)

https://doi.org/10.1387/ijdb.190242sx

\title{
Present status and expectation of aristaless-related homeobox (ARX) in endocrine pancreas
}

\author{
SAI XU*,1,2 and JI-PING XU*, ${ }^{1,2}$ \\ ${ }^{1}$ Shandong Provincial Key Laboratory of Animal Cells and Developmental Biology, School of Life Science, Shandong \\ University, and ${ }^{2}$ Department of Neurology Medicine, Second Hospital of Shandong University, Jinan, Shandong, \\ People's Republic of China
}

\begin{abstract}
The aristaless-related homeobox (ARX) gene has become one of most frequently mutated genes which is closely linked with development of the vertebrate central nervous system; however, the molecular and clinical bases of its function in the proliferation and differentiation of the endocrine pancreas have not, to date, been systematically characterized. ARX is considered as a regulator which determines endocrine cell fate and a bio-marker of the pancreatic $\alpha$-cell. Disruption and mutation of $A R X$ are found to lead to the deletion and reduction of $\alpha$-cells both in mice models and in humans. Furthermore, expression of $A R X$ is regulated by multiple transcription factors involved in development of the pancreas, such as Ngn3, Isl1, Nkx2.2 and Nkx6.1. Taken together, given the vital importance of glucagon in diabetes treatment, it is possible that $A R X$ may down-regulate exorbitant glucagon levels by reducing the number of $\alpha$-cells as a direct target; thus, the role of $A R X$ in the maintenance of $\alpha$-cell identity and quantity should be investigated and summarized. This article mainly focuses on the role of $A R X$ in the endocrine pancreas, introduces the $A R X$-related animal model and transcription factors, and highlights the latest advances in our understanding in order to provide a clearer theoretical foundation for future scientific research.
\end{abstract}

KEY WORDS: ARX, endocrine pancreas, transcription factor, mouse model, apoptosis

Introduction

$A R X$, the Aritaless-related homeobox gene, was isolated and identified from mouse cDNA library by Hirohito Miura et al., in 1997 (Miura et al., 1997). Initially, $A R X$ was characterized in embryos of zebrafish and mice, and found to possess remarkable similarity with Drosophila gene aristaless (Miura et al., 1997). The patients with X-linked diseases such as West syndrome, infantile spasms syndrome, lissencephaly with ambiguous genitalia and intellectual disability, non-syndromic mental retardation and Partington syndrome, were identified to experience $A R X$ gene mutations (Gecz et al., 2006, Shoubridge et al., 2010). Thus the human ortholog was discovered in 2002 followed by above mentioned observations (Bienvenu et al., 2002, Kitamura et al., 2002, Stromme et al., 2002a, Stromme et al., 2002b).

To date, many cases about different $A R X$ mutations carried in human families and several studies on the function and mechanism of $A R X$ has been reported (Friocourt and Parnavelas, 2010, Friocourt and Parnavelas, 2011, Friocourt et al., 2006, Gecz et al., 2006, Olivetti and Noebels, 2012, Shoubridge et al., 2010). However, expression and role of $A R X$ is not only defined in brain. In fact, the disruption or other mutations of $A R X$ are found to lead the deletion or reduction of pancreatic $\alpha$-cells both in mice models and human being (Collombat et al., 2003, Itoh et al., 2010, Wilcox et al., 2013b, $\mathrm{Xu}$ et al., 2013). During this process, Glucagon secreted from $\alpha$ cell is also deficiency. These evidences indicate that Arx not only play pivotal role in the development and proliferation of endocrine cells, but also have the potential effect on glucose homeostasis and glycemic control. All of these illustrate the importance of $A R X$ in development and differentiation of multiple endocrine cells.

Since the discovery of $A R X$, several reviews have introduced its function in vertebrate central nervous system(Friocourt and Parnavelas, 2010, Friocourt and Parnavelas, 2011, Friocourt et al., 2006, Olivetti and Noebels, 2012). It also makes progress in

Abbreviations used in this paper: ARX, aristaless-related homeobox.

\footnotetext{
*Address correspondence to: Sai Xu. Shandong Provincial Key Laboratory of Animal Cells and Developmental Biology, School of Life Science, Shandong University, No. 27 Shanda South Road, Licheng District, Jinan, Shandong 250100, People's Republic of China. Tel: +86-531-88364929. Fax: +86-531-88565610. E-mail: xusai6850@163.com - (iD) https://orcid.org/0000-0002-1765-0566 or Ji-Ping Xu. Shandong Provincial Key Laboratory of Animal Cells and Developmental Biology, School of Life Science, Shandong University, Jinan, Shandong 250100, People's Republic of China. Tel: +86-531-88364929. Fax: +86-531-88565610.

E-mail: xjp0801@126.com - (iD) https://orcid.org/0000-0003-0420-1478
}

Submitted: 29 July, 2019; Accepted: 21 November, 2019.

ISSN: Online 1696-3547, Print 0214-6282 
endocrine research and is necessary to review, analyze and evaluate achievements already obtained in the past 13 years. In this article, the currently available published $A R X$ mutants in pancreas with the associated clinical and experimental phenotypes are listed and summarized. The recent molecular findings and underlying mechanisms are compared and discussed in order to provide a clearer look into the inheritance and pathogenesis of $A R X$.

A
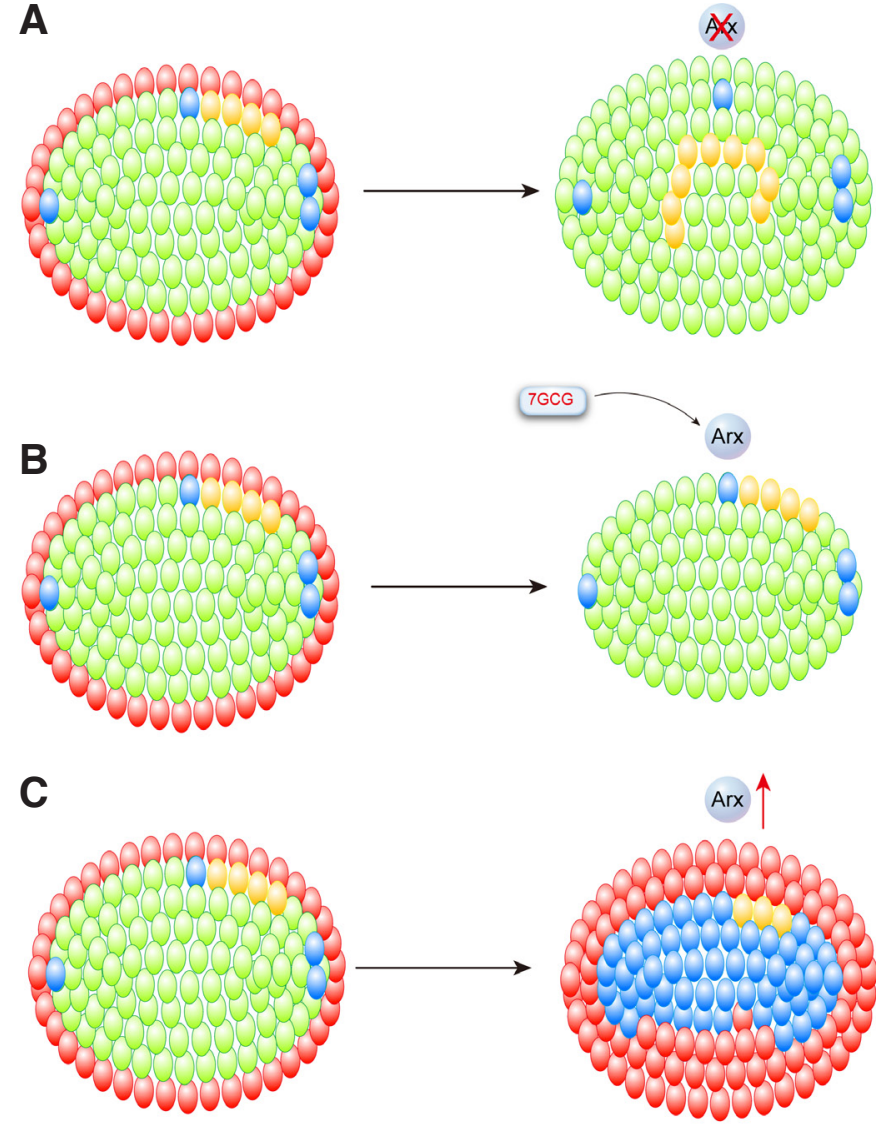

D
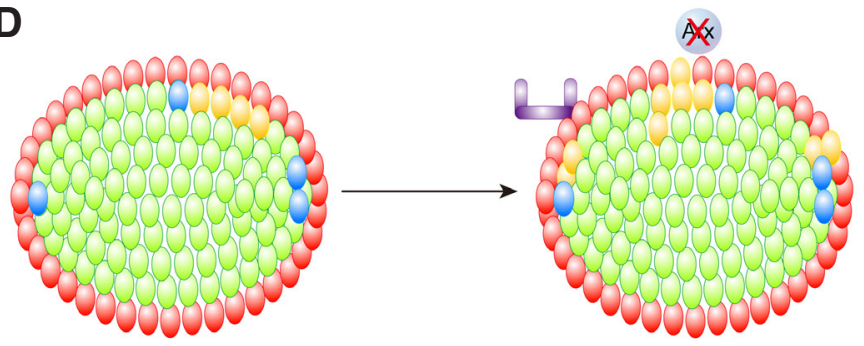

$\alpha$-cell $\beta$-cell

Y- cell

ס-cell

pancreatic ductal cell

endocrine precursor

Fig. 1. Changes in populations of $\alpha-, \beta-, \delta$ - and $\gamma$ - cells by different $\boldsymbol{A} \boldsymbol{R} \boldsymbol{X}$ mutations. (A) Changes of endocrine cell types and population in ARX-null mice model. (B) Changes of endocrine cell types and population in GCG7 mutant (ARX polyalanine expansion) mice model. (C) Changes of endocrine cell types and population in ARX gain-of-function mice model. (D) Changes of endocrine cell types and population in deficient for ARX in mature $\alpha$-cell mice model. Red, $\alpha$-cell; green, $\beta$-cell; yellow, $\delta$-cell; blue, $\gamma$-cell; gray, endocrine precursor; purple, pancreatic ductal cell.

\section{ARX gene and protein}

$A R X$ gene is located at the genomic region Xp22 with a span of $12.25 \mathrm{~kb}$ which holds five coding exons giving rise to a $1686 \mathrm{bp}$ ORF(open reading frame) in human (Gecz et al., 2006, Shoubridge et al., 2010). The mRNA produced by $A R X$ is $2.8-\mathrm{kb}$, and the protein which encoded by $A R X$ gene is made up of 562 amino acid, forming four characteristic polyalanine tracts where most of the mutations occur (Gecz et al., 2006, Shoubridge et al., 2010, Yu et al., 2014).

The Arx protein regulates gene expression as a nuclear transcriptional factor in a variety of tissues and organs. Until now, Arx has been found expression predominately in the testes (Kitamura et al., 2002, Miyabayashi et al., 2013), skeletal muscle(Biressi et al., 2008)[18], pancreatic endocrine cell(Collombat et al., 2003), enterendocrine cell (Beucher et al., 2012, Du et al., 2012, Terry et al., 2015), fetal and adult brain(Ohira et al., 2002, Yoshihara et al., 2005).

In mouse embryo, Arx is expressed starting at embryonic day 9.5 (E9.5) and thereafter throughout whole development stages (Collombat et al., 2003, Miura et al., 1997). It is supposed to be expressed first in the endocrine progenitor cells and then restricted to $\alpha$-cell(Collombat et al., 2003).

\section{Mice models}

To understand its influence in development and differentiation of pancreas, several mice models were made for the investigation. Thus, in this paper, we summarized the physiologic and metabolic feature among these established models. The results may help us understand how $A R X$ gene functions in pancreas of mammalians. The changes in cellular population of $\alpha-, \beta-, \delta$ - and $\gamma$ - cells by different $A R X$ mutations are shown in Fig. 1

\section{ARX -null mice model}

Collombat et al., first established $A R X$-null mice by homologous recombination in embryonice stem (ES) cells. The $\beta$-galactosidase gene and the neomycin resistance gene were used to replace octapeptide, $\alpha$-helix 1 and about half $\alpha$-helix 2 of the homeodomain. Retarded growth and dehydration was observed on $A R X$-null mice. Hyperglycemia was appeared 2 days after birth followed by death(Collombat et al., 2003).

\section{ARX gain-of-function mice model}

Gain-of-function mice were also generated by Collombat et al., in 2007 using transgenic method which showed growth retardation and pancreatic hypoplasia with a shortened life span of 2-12 weeks. Before death, the blood and urinary sugar level was dramatically elevated(Collombat et al., 2007).

\section{Deficient for ARX in pancreatic endocrine cell mice model}

Aidan S. Hancocketal., established $A R X$ deficient mice by solely deleted $A R X$ gene in the pancreatic endocrine cells. Comparing with the wild-type, $A R X$-deficient mice exhibited no difference in body weight, blood glucose. The mice were healthy and the glucose tolerance test was improved and basal hepatic glucose level was reduced and the quantities of glcogenin in the liver were increased(Hancock et al., 2010).

\section{Deficient for ARX in mature $\alpha$-cell mice model}

Two kinds of conditional knockout mice models in which the $A R X$ 


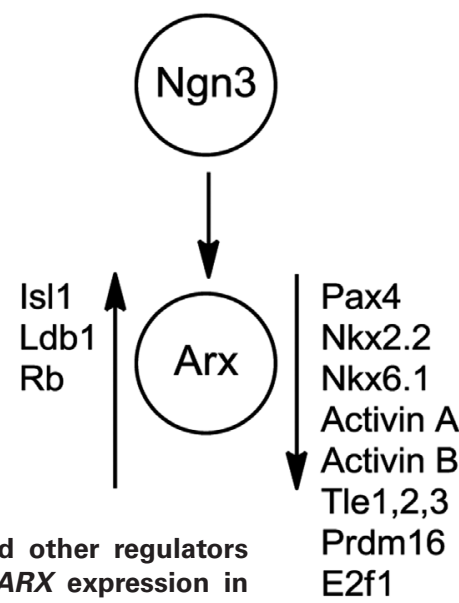

Fig. 2. Transcription factors and other regulators involved in the regulation of $A R X$ expression in the mouse model. ARX acts downstream of NGN3 in endocrine precursors and promotes $\alpha$-cell fate with the help of Is I , Ldb1 and $R b$ proteins. In contrast, the transcription factor cascade including Pax4, Nkx2.2, Nkx6.1, ActivinA, ActivinB, Prdm16, E2F1, Tle1, 2 and 3 represses the expression of $\mathrm{ARX}$ in $\beta$-cells.

gene had been ablated specifically in $\alpha$-cell were set by Catherine Lee May (Wilcox et al., 2013b) and Patrick Collombat's laboratories. One of them established by Patrick Collombat's laboratory could selective inhibited Arx gene in $\alpha$-cell at any developmental stages(Courtney et al., 2013).

Both of the two mice models were found viable and fertile, their life expectancy and basal glycemia remaining within normal range. In addition, they showed an increased capacity to counteract the glucose bolus with a lower peak in glycemia in intraperitoneal glucose tolerance test (Courtney et al., 2013, Wilcox et al., 2013b).

\section{Other ARX mutant mice models}

Kunio Kitamura et al., introduced three $A R X$ mutant mice in 2009 (Kitamura et al., 2009). Among these mice models, two types were used in the endocrinology research.

\section{GCG7 mutant mice}

At residue 330 of the mouse $A R X$ gene, seven GCG-triplets were inserted to generate GCG7 mutant(Kitamura et al., 2009). Most of them survived for 3-4 months, few last till 5-6 months (Kitamura et al., 2009, Xu et al., 2013). GCG7 mutant mouse was analyzed as $A R X$ expanded model in genetic study, and its $A R X$ mRNA level was significantly down-regulated to approximately $30 \%$ of wild-type level in E15.5 pancreata(Wilcox et al., 2013a).

\section{P355L mutant mice}

The proline residue at the position of 355 was changed to leucine to generate $P 355 \mathrm{~L}$ mutant mice. These mice survived for more than 6 months and western blotting showed that the Arx protein from forebrain was also deceased but not as severe as GCG7 mutant mice and the total mRNA level from embryo was also not changed (Kitamura et al., 2009).

\section{$A R X$-related transcription factors and regulators}

After realized the phenotypes shown in these mice models mentioned above, function of $A R X$ in islet of Langerhans raised researchers' attention. In the network of development and survival of endocrine cells, the role of $A R X$ and the transcription factors related to it should be fully studied. Here we introduce several transcription factors and describe the relationship with $A R X$ via researches since 2003, which is shown in Fig. 2, aim to comprehensive understand the molecular mechanism of $A R X$ in pancreas and expand the way of thinking for intensive research in future.

\section{Ngn3}

The bHLH transcription factor neurogenin3 ( Ngn3) is an early marker of cells differentiating toward a primary endocrine fate (Habener et al., 2005, Rukstalis and Habener, 2009). Ngn3-null mice exhibit endocrine precursor cell generation failure while overexpression results in acceleration of differentiation (Apelqvist et al., 1999, Gradwohl et al., 2000, Gu et al., 2002, Johansson et al., 2007) and the Arx protein is not expressed in pancreas(Collombat et al., 2003), which suggests a potential role in $A R X$ downstream of NGN3 in islet of Langerhans developmental processes.

\section{Pax4}

The transcription factor Pax4 is a paired-box homeoprotein functions early in the development of islet cells to promote the differentiation of $\beta$ - and $\delta$-cells (Habener et al., 2005, Napolitano et al., 2015, Sosa-Pineda et al., 1997). Arx and Pax4 is a pair of reciprocal repression transcription factors. Pax 4 promotes $\beta$ - and $\delta$-cell fates, whereas Arx favors $\alpha$-cell destiny(Collombat et al., 2003). Both of them act as transcriptional repressors that control the expression level of another one to mediate the proper endocrine fate allocation. It is noteworthy to mention that, Arx has maintained its role in $\alpha$-cell differentiation from fish to mammals, but Pax4 has no apparent function in the formation of $\beta$-cell in zebrafish embryos which indicates that Pax4 acquired its essential role in $\beta$-cells differentiation quite late in vertebrates' evolution(Djiotsa et al., 2012).

\section{Is/1 and Ldb1}

The LIM homeodomain protein islet1 (Is/1) could be detected in multiple tissues and represents the first known activator of $A R X$ transcription in $\alpha$-cells (Zhuang et al., 2013). Experiment results indicate ISL1gene is required for the development of dorsal pancreatic mesenchyme and essential for the formation and proliferation of endocrine cells(Ahlgren et al., 1997, Guo et al., 2011).The LIM domain-binding protein 1 (Ldb1) is essential for Isl1 biological activity as a cofactor(Agulnick et al., 1996, Makarev and Gorivodsky, 2014) which distributed in the early pancreatic epithelium and surrounding mesenchyme, and finally expressed in mature endocrine and ductal cells. Removal of Ldb1 in embryonic endocrine cells leads to the down-regulation of $A R X$ expression(Hunter et al., 2013).

\section{Tle1, Tle2 and Tle3}

The Groucho family members, containing transducin-like enhancer of split1 (Tle1), Tle2, Tle3 and Tle4 act as transcriptional co-repressors and are overlapping expressed during the development of pancreas(Chen and Courey, 2000, Jennings and Ish-Horowicz, 2008). Tle2 can interact with several transcription factors involved in development and proliferation of pancreas to modulate the repressive abilities of $A R X$ in $\beta$-cell line(Hoffman et al., 2008). Ectopic expression of Tle3 in $\alpha$-cells represses glucagon and $A R X$. And the function of Tle1 is similar to Tle3 in endocrine cells (Metzger et al., 2014). 


\section{Nkx2.2 and Nkx6.1}

The member of NK2 family transcription factor, Nkx2.2 is required for the development and differentiation of pancreatic endocrine cells(Balderes et al., 2013, Sussel et al., 1998). Nkx2.2 regulates expression of $A R X$ as a transcription repressor in endocrine cells. Deficiency of $N K X 2.2$ leads to a severely loss of $\beta$-cells and reduction of $\alpha$ - and $\gamma$-cells, and increase of $\varepsilon$-cells in mouse embryo(Kordowich et al., 2011, Mastracci et al., 2011). Nkx6.1 lies downstream of Nkx2.2 in the development of islet(Sander et al., 2000). The expression of Nkx6.1 persists in multipotent pancreatic progenitor in early developmental stage. $\mathrm{Nkx6.1}$ and Isl1 regulate Nkx6.1 binds and repress $A R X$ via occupies the conserved $\mathrm{Re}$ control domain(Schaffer et al., 2013).

Activins, including activin $A$, activin $A B$ and activin $B$ are disulfide$A R X$ antagonistically for determining $\alpha$ - and $\beta$-cell fate, in which

\section{Activin A and B}

linked homodimers of inhibin $\beta$ subunits(Dani, 2013, Refaat, 2014), which suppress critical $\alpha$-cell gene expression, including $A R X$, in $\alpha$-cells and enhances the expression of $\beta$-cellgenes, including $P A X 4$, in $\beta$-cells(Andrzejewski et al., 2015, Mamin and Philippe, 2007).

\section{Prdm16}

PR domain-containing 16(Prdm16) is expressed in fetal pancreatic epithelial cells including $\mathrm{Ngn}^{+}$cells, and deficiency of Prdm16 leads to significantly increase of $A R X$ expression in endocrinal cells, together with hyperplasia of $\alpha$-cells and $\gamma$-cells(Sugiyama et al., 2013).

\section{$R b$ and E2f1}

The retinoblastoma protein $(\mathrm{Rb})$ is always mentioned with the transcription factor E2f1 as a whole required for cell cycle progression in autophagy or apoptosis pathway(Laine and Westermarck, 2014, Udayakumar et al., 2010, Wu and Yu, 2009). Rb phosphorylation leads to its dissociation from E2f1, and the inhibition of transactivation is removed(Mayank et al., 2014, Sahin and Sladek, 2010, Sun et al., 2010). It is found that a conserved E2f1 binding site locates in exon 2 of $A R X$ gene, and Rb blocks the $A R X$ gene repression by binding to E2f1(Cai et al., 2013). Overall, the absence of Rb leads to an increase in E2f1 and repression of Arx, in contract, E2f1 knockdown restored Arx levels in $\alpha$-cells.

By the above experimental results, location of Arx is clear distinguished in the signal network for development and specification of pancreatic endocrine cells. Some multipotent pancreatic progenitors express the endocrine specific transcription factor Ngn3 and differentiate into committed islet endocrine precursors, and then Arx is expressed in the process from endocrine precursors to $\alpha$-cells. Though analysis of the role and starting expression time of other transcription factors which repress expression of Arx, there are reasons to believe that Arx is inhibited by Nkx2.2, Nkx6.1 and other $\beta$-cell specific transcription factors mentioned above in the development of $\beta$-cell.

\section{C}

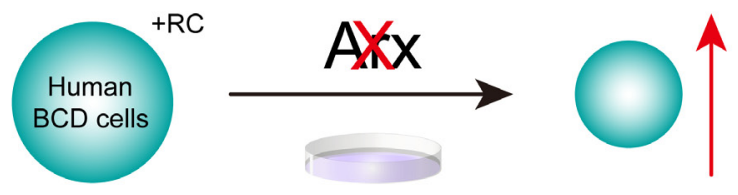

\section{The role of ARX in the pancreas}

\section{Differentiation and conversation}

Deficiency of Arx leads to the absence of $\alpha$-cell and decrease in partial glucagon and ghrelin coexpressing cell number which does not give rise to

Fig. 3. Changes in the endocrine cell population by inhibition of $\boldsymbol{A R X}$. (A) The complete loss of $\alpha$-cells with a concomitant increase in $\beta$ - and $\delta$-cell numbers in ARX-null mice. (B) The complete loss of $\alpha$-cells with a drastic decrease in $\beta$-cell number and an increase in $\delta$-cell number in pancreatic endocrine specification of ARX knockout hESCs. (C) $\beta$-cell dedifferentiation is inhibited by misactivation of ARX in RC-treated BCD cells. (D) $\alpha$ - to- $\beta$-cell conversion is not induced by misactivation of ARX in RC-treated ACD cells. Red, $\alpha$-cell; green, $\beta$-cell; yellow, $\delta$-cell; $h E S C$, human embryonic stem cell; $R C$, redifferentiation cocktail la combination of solube factors); BCD cells, $\beta$-cell-derived cells; ACD cells, $\alpha$-cell-derived cells. 
the total endocrine cell mass. That is to say, variation of $\alpha$-cell number is accompanied by the opposite changes in $\beta$ - and $\delta$-cell number(Collombat et al., 2003, Hancock et al., 2010). It is general thought that islet subtype destiny is directed by cross-repression of the reciprocal transcription factors Arx and Pax4, and the simultaneous loss of $A R X$ and $P A X 4$ genes promotes the $\delta$-cell fate specification at the expense of $\alpha$ - and $\beta$-cells(Collombat et al., 2005, Collombat et al., 2009).

$A R X$ inactivation could induce the $\alpha$-to- $\beta$-cell reprogramming in pancreatic progenitor cells or mature $\alpha$-cells at any developmental or age stages, including embryonic, neonatal or mature stages(Collombat et al., 2003, Courtney et al., 2013, Hancock et al., 2010). The $\alpha$-cell identity appears through an intermediate bihormonal state and is transformed into $\beta$-cell in the final(Wilcox et al., 2013b). The $\alpha$-to- $\beta$-cell conversion induced by $A R X$ seems not to stop until all $\alpha$-cells change to $\beta$-cells totally(Courtney et al., 2013).The ectopic expression of $A R X$ induces in progenitor or mature $\beta$-cells leads to a loss of the $\beta$-cell identity and a dramatic increase in a number of $\alpha$ - and $\gamma$-cells(Collombat et al., 2007), which means $A R X$ is probably deactivated in $\beta$-cell. Thus how to suppress activeness of $A R X$ in $\beta$-cell, and how to activate the function of $A R X$ in $\beta$-cell has become a hotspot, and the epigenetics study gives us some inspiration(van der Meulen and Huising, 2015). It is found that methylation of $A R X$ plays critical role in determining the identity of different pancreatic endocrine cells, and $A R X$ is hypomethylated in $\alpha$-cell and methylated in $\beta$-cell(Dhawan et al., 2011). In differentiated $\beta$-cells, the $A R X$ promoter is highly methylated and this is facilitated by the de novo DNA methytransferase Dnmt3a(Chen and Chan, 2014, Papizan et al., 2011). Transcription factor Nkx2.2 binds the hypermethylated promoter of $A R X$, in a complex with Dnmt3a and preferentially recruits Tle3 and HDAC1 to repress $A R X$ (Papizan et al., 2011, Schaffer et al., 2013). In the proliferation and regeneration of $\beta$-cells, the $A R X$ regulatory region maintains methylation status induced by another DNA methyltransferase Dnmt 1 to prevent the decrease of DNA methylation in $\beta$-cell division(Dhawan et al., 2011, Nishiyama et al., 2016). Furthermore, methylated region of the $A R X$ locus in $\beta$-cells is bound by the methyl-binding protein MeCP2, which recruits the HMT PRMT6 that mediates H3R2 methylation, resulting in repression of $A R X$ (Dhawan etal., 2011), which is shown in Fig. 4. The following experiments demonstrate that Deficiency of Dnmt1 or Dnmt3a both lead to the $\beta$-to- $\alpha$-cell conversion (Dhawan et al., 2011, Papizan et al., 2011). However, it is still unknown that which $\beta$-cell specific factor perferential recruit Dnmt3a in this process because Dnmt3a is also expressed in both $\alpha$ - and $\beta$-cell(Papizan et al., 2011). The different pathway of Dnmt3a in $\alpha$ - and $\beta$-cell should be next research focus in the future. Moreover, another experiment showed that within 3 months of Dnmt1 and Arx loss, lineage tracing and single-cell RNA sequencing revealed extensive $\alpha$ cell conversion into progeny resembling native $\beta$ cells, which indicated that pathways regulated by Arx and Dnmt1 that were sufficient for achieving targeted generation of $\beta$ cells from adult pancreatic $\alpha$ cells(Chakravarthy et al., 2017).

In addition, pancreatic G-cell which could secret hormone gastrin has been recently identified in embryonic islet as $6^{\text {th }}$ endocrine cell type, and its formation depends on $A R X$. Relevant data suggest that $70 \%$ reduction in the levels of gastrin mRNA in embryos of mice deficient for $A R X$ (Suissa et al., 2013). Since $\mathrm{G}$ cell has

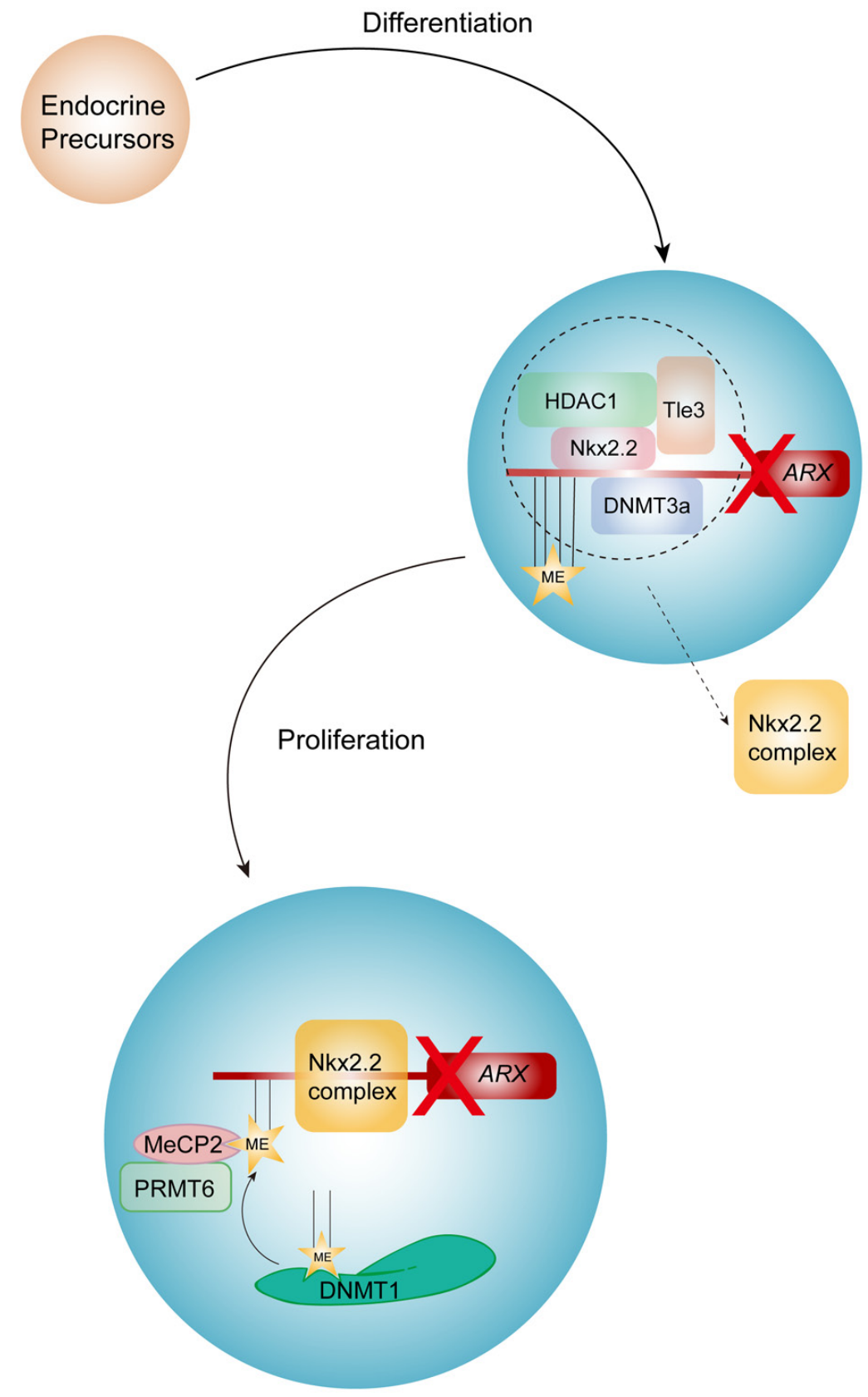

Fig. 4. $\beta$-cell identity is maintained by DNA-methylation-mediated repression of $\boldsymbol{A R X}$. Nkx2.2 binds the hypermethylated promoter of ARX, in a complex with Dnmt3a and preferentially recruits Tle3 and HDAC1 to repress ARX in differentiated $\beta$-cells. In the proliferation and regeneration of $\beta$-cells, the ARX regulatory region maintains methylation status induced by Dnmt1, and the methylated region of the ARX locus in $\beta$-cells is bound by the methyl-binding protein MeCP2, which recruits the HMT PRMT6 that mediates H3R2 methylation, resulting in repression of ARX. Blue, $\beta$-cell; orange, endocrine precursor; $M E$, methylation status. 
just been discovered in pancreas, correlative research reports are few and the relationship between gastrin and $A R X$ shall be clarified by further study.

\section{Apoptosis}

Recently some studies show that several $A R X$ mutations could lead to apoptosis of $\alpha$-cells (Wilcox et al., 2013a, Xu et al., 2013) which is originally proposed in the research on hyperplasia of $\alpha$-cells induced by absolute or relative deficiency of glucagon secretion in vivo(Hayashi et al., 2009). It is found that expression of $A R X \mathrm{mRNA}$ is extremely up-regulated in the huge pancreas of mice lacked pro-glucagon gene, and this compensatory hyperemia could be depressed when $A R X$ gene is mutated in vivo, including GCG7 and P335L mutations (Hayashi, 2011, Hayashi et al., 2009, $\mathrm{Xu}$ et al., 2013). In this case the reduction of pancreatic $\alpha$-cell could be due to an increasing $\alpha$-cell apoptosis, while the $\beta$-cell mass remain no change and some $\beta$-cell specific transcription factors show no significantly up-regulated.

Similar results are obtained by analysis on the pancreas of patients with $A R X$ mutations. Itoh $M$ et al., firstly revealed the abnormal distribution of the component cells of Langerhans islets and the exocrine system of two male XLAG patients with $A R X$ mutation in 2010. Both of them died before the second year with various mutation or deletion of nucleotide changes in $A R X$ gene. Abnormal gene sequences lead to severe clinical presentations including relatively smaller pancreases followed by increase of fibrous interstitium and small islets of Langerhans showed deficient of $\alpha$ - and $\gamma$-cells(Itoh et al., 2010). However, the number of $\beta$-, $\delta$ - and $\varepsilon$ - cells are not significant reduced compared with those of the age-matched controls, and the transcription factor Brn4 and Pax6 which both bind to the progulcagon gene promoter is not detected in the pancreas with Arx mutations(Gosmain et al., 2011, Itoh et al., 2010).

With the help of those animal experimental and clinical results, it is obviously demonstrated that a different pathway is regulated and affected. For instance, Rb and E2f1 pathway is closely associated with tumor suppressor p53 and p16 which have a significant role in apoptosis, autophagy and senescence(James and Peters, 2000, Laine and Westermarck, 2014, Madan et al., 2012, Udayakumar et al., 2010). It is possibility that the binding capacity is changed by site-directed mutagenesis in exon2 of $A R X$ gene, which results in up-regulation of apoptosis factors. Naturally it is a conjecture or hypothesis based on known pathway, the definite mechanism should be verified by detailed experimental analysis.

\section{Expectation and conclusion}

$A R X$ gene has been in our sight for a time. According to the previous research on pancreas, it is considered as one of determined factors for early specification of $\alpha$-cell and maintenance of $\alpha$-cell identity, but not directly involved in glucagon expression, and common used as a specific $\alpha$-cell biomarker to analysis the change and fate of endocrine cell types(Rezania et al., 2011, Riedel et al., 2012).

Current research into diabetes treatment, especially type 1 diabetes caused by the loss of $\beta$-cells and insulin secreted, is focus on generating replacement cells from other sources, including stem cells, progenitor cells and differentiated cells(Courtney et al., 2011). ARX inactivation is expected to induce stem cell or other mature pancreatic endocrine cell in to insulin-producing cell as an essential factor(Pearl and Horb, 2008). Surprisingly, the experiment in vitro suggests that $A R X$ inhibition does not have obvious effective on the trandifferentiation into $\beta$-cells in differentiated human embryonic stem cells using 33-day and7satges protocol or expanded $\alpha$-cells treated with a combination of solube factors(Gage et al., 2015). However, misactivation of $A R X$ inhibits the redifferentation of ex-vivo expansion of $\beta$-cells, elevates insulin mRNA levels and increases the productivity of insulin-positive cells, which suggests $A R X$ blocking could be an effective approach of facilitate the generation of abundant $\beta$-cells under defined conditions(Friedman-Mazursky et al., 2016).

Several lines of evidence indicate that $\alpha$-cells could be other potential progenitors of $\beta$-cells in vivo(Habener and Stanojevic, 2013). It is well known that $\beta$-cell self-replication can be used to supplement relative and absolute deficiency of insulin-producing cells in $\beta$-cell injury or diabetes model, however, this system would failure if the ablation of $\beta$-cells were extreme(Bouwens and Rooman, 2005). In this case, the regeneration of new $\beta$-cells mainly depends on the directly transdifferentiation from preexisting $\alpha$-cells(Habener and Stanojevic, 2013). Recent study shows that a prompt expansion of $\beta$-cells occurred in mice with special ablation of $A R X$ in mature $\alpha$-cells. It can be inferred that the decrease of glucagon signaling induces pancreatic duct cells re-express NGN3 and continuously differentiate into $\alpha$-cell, however, these neogenic $\alpha$-cells are convert into $\beta$-cells gradually owing to the deficiency of $A R X(C o u r t n e y$ et al., 2013). These evidences suggest that $A R X$ could be used in generating $\beta$-cells as a potential target in diabetes treatment.

Still a bit not allow to ignore, the security of $A R X$ suppression should be considered as a vital dimension. Although $A R X$-null mice die within 2 days after birth, its role in pancreas is not the main cause of mortality(Collombat et al., 2003, Hancock et al., 2010). The decrease of $\alpha$-cells caused by disruption of $A R X$ couldn't lead to severe metabolism physiologically changes in maturity individuals(Hancock et al., 2010). This conclusion is consistent with previous findings that the blood glucose level and life span maintain normal in the mice deficient for pro-glucagon gene(Hancock et al., 2010, Hayashi et al., 2009). Furthermore, the second worry is fatty liver owing to the absence of serum glucagon level (Hancock et al., 2010). In fact, different mutation type and mutation site have important impact on the $\alpha$-cell fate, and some evidences indicate that precious few $\alpha$-cells $98 \% \alpha-$ cell ablation could adjust and maintain normal serum glucagon level over time(Thorel et al., 2011). There are reasons to believe that this fatty liver case could be avoided. Taken together, it can be speculated that $A R X$ is a reliable and safe target for diabetes treatment.

\section{Concluding remarks}

Although the molecular pathway and pathogenesis still remain puzzling, what's clear is that the role of $A R X$ is vital to the endocrine cell fate, especially $\alpha$-cell identity and survival. With the technical development and the research being unceasingly thorough, there are more profound recognitions to the function of $A R X$ in endocrine pancreas. These progresses on experimental biology and clinical medicine have been of great benefit for scientific advancement and treating disease. Based on the existent 
knowledge and experiences, the utilization of $A R X$ is worth looking forward in diabetes therapy.

\section{Conflict of interest}

The authors declare they have no competing interests or other interests that might be perceived to influence the results and discussion reported in this paper.

\section{References}

AGULNICK, A.D., TAIRA, M., BREEN, J.J., TANAKA, T., DAWID, I.B. and WESTPHAL, H. (1996). Interactions of the LIM-domain-binding factor Ldb1 with LIM homeodomain proteins. Nature 384: 270-272.

AHLGREN, U., PFAFF, S.L., JESSELL, T.M., EDLUND, T. and EDLUND, H. (1997). Independent requirement for ISL1 in formation of pancreatic mesenchyme and islet cells. Nature $385:$ 257-260.

ANDRZEJEWSKI, D., BROWN, M.L., UNGERLEIDER, N., BURNSIDE, A. and SCHNEYER, A.L. (2015). Activins A and B Regulate Fate-Determining Gene Expression in Islet Cell Lines and Islet Cells From Male Mice. Endocrinology 156: $2440-2450$.

APELQVIST, A., LI, H., SOMMER, L., BEATUS, P., ANDERSON, D.J., HONJO, T., HRABE DE ANGELIS, M., LENDAHL, U. and EDLUND, H. (1999). Notch signalling controls pancreatic cell differentiation. Nature 400: 877-881.

BALDERES, D.A., MAGNUSON, M.A. and SUSSEL, L. (2013). Nkx2.2:Cre knock-in mouse line: a novel tool for pancreas- and CNS-specific gene deletion. Genesis 51: 844-851.

BEUCHER, A., GJERNES, E., COLLIN, C., COURTNEY, M., MEUNIER, A., COLLOMBAT, P. and GRADWOHL, G. (2012). The homeodomain-containing transcription factors Arx and Pax4 control enteroendocrine subtype specification in mice. PLoS One 7: e36449.

BIENVENU, T., POIRIER, K., FRIOCOURT, G., BAHI, N., BEAUMONT, D., FAUCHEREAU, F., BEN JEEMA, L., ZEMNI, R., VINET, M.C., FRANCIS, F. et al., (2002). ARX, a novel Prd-class-homeobox gene highly expressed in the telencephalon, is mutated in X-linked mental retardation. Hum Mol Genet 11: 981-991.

BIRESSI, S., MESSINA, G., COLLOMBAT, P., TAGLIAFICO, E., MONTEVERDE, S., BENEDETTI, L., CUSELLA DE ANGELIS, M.G., MANSOURI, A., FERRARI, S., TAJBAKHSH, S. et al., (2008). The homeobox gene Arx is a novel positive regulator of embryonic myogenesis. Cell Death Differ 15: 94-104.

BOUWENS, L. and ROOMAN, I. (2005). Regulation of pancreatic beta-cell mass. Physiol Rev 85: 1255-1270.

CAI, E.P., WU, X., SCHROER, S.A., ELIA, A.J., NOSTRO, M.C., ZACKSENHAUS, E. and WOO, M. (2013). Retinoblastoma tumor suppressor protein in pancreatic progenitors controls alpha- and beta-cell fate. Proc Natl Acad Sci USA 110: 14723-14728.

CHAKRAVARTHY, H., GU, X., ENGE, M., DAI, X., WANG, Y., DAMOND, N., DOWNIE, C., LIU, K., WANG, J., XING, Y. etal., (2017). Converting Adult Pancreatic Islet alpha Cells into beta Cells by Targeting Both Dnmt1 and Arx. Cell Metab 25: 622-634.

CHEN, B.F. and CHAN, W.Y. (2014). The de novo DNA methyltransferase DNMT3A in development and cancer. Epigenetics 9: 669-677.

CHEN, G. and COUREY, A.J. (2000). Groucho/TLE family proteins and transcriptional repression. Gene 249: 1-16.

COLLOMBAT, P., HECKSHER-SORENSEN, J., BROCCOLI, V., KRULL, J., PONTE, I., MUNDIGER, T., SMITH, J., GRUSS, P., SERUP, P. and MANSOURI, A. (2005). The simultaneous loss of Arx and Pax 4 genes promotes a somatostatin-producing cell fate specification at the expense of the alpha- and beta-cell lineages in the mouse endocrine pancreas. Development 132: 2969-2980.

COLLOMBAT, P., HECKSHER-SORENSEN, J., KRULL, J., BERGER, J., RIEDEL, D., HERRERA, P.L., SERUP, P. and MANSOURI, A. (2007). Embryonic endocrine pancreas and mature beta cells acquire alpha and PP cell phenotypes upon Arx misexpression. J Clin Invest 117: 961-970.

COLLOMBAT, P., MANSOURI, A., HECKSHER-SORENSEN, J., SERUP, P., KRULL, J., GRADWOHL, G. and GRUSS, P. (2003). Opposing actions of Arx and Pax4 in endocrine pancreas development. Genes Dev 17: 2591-2603.

COLLOMBAT, P., XU, X., RAVASSARD, P., SOSA-PINEDA, B., DUSSAUD, S., BILLESTRUP, N., MADSEN, O.D., SERUP, P., HEIMBERG, H. and MANSOURI, A.
(2009). The ectopic expression of $\mathrm{Pax} 4$ in the mouse pancreas converts progenitor cells into alpha and subsequently beta cells. Cell 138: 449-462.

COURTNEY, M., GJERNES, E., DRUELLE, N., RAVAUd, C., VIEIRA, A., BENOTHMAN, N., PFEIFER, A., AVOLIO, F., LEUCKX, G., LACAS-GERVAIS, S. et al., (2013). The inactivation of Arx in pancreatic alpha-cells triggers their neogenesis and conversion into functional beta-like cells. PLoS Genet 9: e1003934.

COURTNEY, M., PFEIFER, A., AL-HASANI, K., GJERNES, E., VIEIRA, A., BENOTHMAN, N. and COLLOMBAT, P. (2011). In vivo conversion of adult alpha-cells into beta-like cells: a new research avenue in the context of type 1 diabetes. Diabetes Obes Metab 13 Suppl 1: 47-52.

DANI, C. (2013). Activins in adipogenesis and obesity. Int J Obes (Lond) 37: 163-166.

DHAWAN, S., GEORGIA, S., TSCHEN, S.I., FAN, G. and BHUSHAN, A. (2011) Pancreatic beta cell identity is maintained by DNA methylation-mediated repression of Arx. Dev Cell 20: 419-429.

DJIOTSA, J., VERBRUGGEN, V., GIACOMOTTO, J., ISHIBASHI, M., MANNING, E., RINKWITZ, S., MANFROID, I., VOZ, M.L. and PEERS, B. (2012). Pax4 is not essential for beta-cell differentiation in zebrafish embryos but modulates alpha-cell generation by repressing arx gene expression. BMC Dev Biol 12: 37 .

DU, A., MCCRACKEN, K.W., WALP, E.R., TERRY, N.A., KLEIN, T.J., HAN, A., WELLS, J.M. and MAY, C.L. (2012). Arx is required for normal enteroendocrine cell development in mice and humans. Dev Biol 365: 175-188.

FRIEDMAN-MAZURSKY, O., ELKON, R. and EFRAT, S. (2016). Redifferentiation of expanded human islet beta cells by inhibition of ARX. Sci Rep 6: 20698.

FRIOCOURT, G. and PARNAVELAS, J.G. (2010). Mutations in ARX Result in Several Defects Involving GABAergic Neurons. Front Cell Neurosci 4: 4.

FRIOCOURT, G. and PARNAVELAS, J.G. (2011). Identification of Arx targets unveils new candidates for controlling cortical interneuron migration and differentiation. Front Cell Neurosci 5: 28.

FRIOCOURT, G., POIRIER, K., RAKIC, S., PARNAVELAS, J.G. and CHELLY, J. (2006). The role of ARX in cortical development. Eur J Neurosci 23: 869-876.

GAGE, B.K., ASADI, A., BAKER, R.K., WEBBER, T.D., WANG, R., ITOH, M., HAYASHI, M., MIYATA, R., AKASHI, T. and KIEFFER, T.J. (2015). The Role of ARX in Human Pancreatic Endocrine Specification. PLoS One 10: e0144100.

GECZ, J., CLOOSTERMAN, D. and PARTINGTON, M. (2006). ARX: a gene for al seasons. Curr Opin Genet Dev 16: 308-316.

GOSMAIN, Y., CHEYSSAC, C., HEDDAD MASSON, M., DIBNER, C. and PHILIPPE, $J$ J. (2011). Glucagon gene expression in the endocrine pancreas: the role of the transcription factor Pax6 in alpha-cell differentiation, glucagon biosynthesis and secretion. Diabetes Obes Metab 13 Suppl 1: 31-38.

GRADWOHL, G., DIERICH, A., LEMEUR, M. and GUILLEMOT, F. (2000). neurogenin 3 is required for the development of the four endocrine cell lineages of the pancreas. Proc Natl Acad Sci USA 97: 1607-1611.

GU, G., DUBAUSKAITE, J. and MELTON, D.A. (2002). Direct evidence for the pancreatic lineage: NGN3+ cells are islet progenitors and are distinct from duct progenitors. Development 129: 2447-2457.

GUO, T., WANG, W., ZHANG, H., LIU, Y., CHEN, P., MA, K. and ZHOU, C. (2011). ISL1 promotes pancreatic islet cell proliferation. PLoS One 6: e22387.

HABENER, J.F., KEMP, D.M. and THOMAS, M.K. (2005). Minireview: transcriptional regulation in pancreatic development. Endocrinology 146: 1025-1034.

HABENER, J.F. and STANOJEVIC, V. (2013). Alpha cells come of age. Trends Endocrinol Metab 24: 153-163.

HANCOCK, A.S., DU, A., LIU, J., MILLER, M. and MAY, C.L. (2010). Glucagon deficiency reduces hepatic glucose production and improves glucose tolerance in adult mice. Mol Endocrinol 24: 1605-1614.

HAYASHI, Y. (2011). Metabolic impact of glucagon deficiency. Diabetes Obes Metab 13 Suppl 1: 151-157.

HAYASHI, Y., YAMAMOTO, M., MIZOGUCHI, H., WATANABE, C., ITO, R., YAMAMOTO, S., SUN, X.Y. and MURATA, Y. (2009). Mice deficient for glucagon genederived peptides display normoglycemia and hyperplasia of islet \{alpha\}-cells but not of intestinal L-cells. Mol Endocrinol 23: 1990-1999.

HOFFMAN, B.G., ZAVAGLIA, B., BEACH, M. and HELGASON, C.D. (2008). Expression of Groucho/TLE proteins during pancreas development. BMC Dev Bio/ 8: 81.

HUNTER, C.S., DIXIT, S., COHEN, T., EDIGER, B., WILCOX, C., FERREIRA, M., WESTPHAL, H., STEIN, R. and MAY, C.L. (2013). Islet alpha-, beta-, and deltacell development is controlled by the Ldb1 coregulator, acting primarily with the 
islet-1 transcription factor. Diabetes 62: 875-886.

ITOH, M., TAKIZAWA, Y., HANAI, S., OKAZAKI, S., MIYATA, R., INOUE, T., AKASHI, T., HAYASHI, M. and GOTO, Y. (2010). Partial loss of pancreas endocrine and exocrine cells of human ARX-null mutation: consideration of pancreas differentiation. Differentiation 80: 118-122.

JAMES, M.C. and PETERS, G. (2000). Alternative product of the p16/CKDN2A locus connects the Rb and p53 tumor suppressors. Prog Cell Cycle Res 4: 71-81.

JENNINGS, B.H. and ISH-HOROWICZ, D. (2008). The Groucho/TLE/Grg family of transcriptional co-repressors. Genome Biol 9: 205.

JOHANSSON, K.A., DURSUN, U., JORDAN, N., GU, G., BEERMANN, F., GRADWOHL, G. and GRAPIN-BOTTON, A. (2007). Temporal control of neurogenin3 activity in pancreas progenitors reveals competence windows for the generation of different endocrine cell types. Dev Cell 12: 457-465.

KITAMURA, K., ITOU, Y., YANAZAWA, M., OHSAWA, M., SUZUKI-MIGISHIMA, R., UMEKI, Y., HOHJOH, H., YANAGAWA, Y., SHINBA, T., ITOH, M. et al., (2009). Three human ARX mutations cause the lissencephaly-like and mental retardation with epilepsy-like pleiotropic phenotypes in mice. Hum Mol Genet 18: 3708-3724.

KITAMURA, K., YANAZAWA, M., SUGIYAMA, N., MIURA, H., IIZUKA-KOGO, A., KUSAKA, M., OMICHI, K., SUZUKI, R., KATO-FUKUI, Y., KAMIIRISA, K. et al., (2002). Mutation of ARX causes abnormal development of forebrain and testes in mice and X-linked lissencephaly with abnormal genitalia in humans. Nat Genet 32: 359-369.

KORDOWICH, S., COLLOMBAT, P., MANSOURI, A. and SERUP, P. (2011). Arx and Nkx2.2 compound deficiency redirects pancreatic alpha- and beta-cell differentiation to a somatostatin/ghrelin co-expressing cell lineage. BMC Dev Biol 11: 52.

LAINE, A. and WESTERMARCK, J. (2014). Molecular pathways: harnessing E2F1 regulation for prosenescence therapy in p53-defective cancer cells. Clin Cancer Res 20: 3644-3650.

MADAN, E., GOGNA, R., KUPPUSAMY, P., BHATT, M., PATI, U. and MAHDI, A.A. (2012). TIGAR induces p53-mediated cell-cycle arrest by regulation of RB-E2F1 complex. Br J Cancer 107: 516-526.

MAKAREV, E. and GORIVODSKY, M. (2014). Islet1 and its co-factor Ldb1 are expressed in quiescent cells of mouse intestinal epithelium. PLoS One 9: e95256.

MAMIN, A. and PHILIPPE, J. (2007). Activin A decreases glucagon and arx gene expression in alpha-cell lines. Mol Endocrinol 21: 259-273.

MASTRACCI, T.L., WILCOX, C.L., ARNES, L., PANEA, C., GOLDEN, J.A., MAY, C.L. and SUSSEL, L. (2011). Nkx2.2 and Arx genetically interact to regulate pancreatic endocrine cell development and endocrine hormone expression. Dev Bio/359:1-11.

MAYANK, A.K., SHARMA, S., DESHWAL, R.K. and LAL, S.K. (2014). LIMD1 antagonizes E2F1 activity and cell cycle progression by enhancing Rb function in cancer cells. Cell Biol Int 38: 809-817.

METZGER, D.E., LIU, C., ZIAIE, A.S., NAJI, A. and ZARET, K.S. (2014). Grg3/TLE3 and Grg1/TLE1 induce monohormonal pancreatic beta-cells while repressing alpha-cell functions. Diabetes 63: 1804-1816.

MIURA, H., YANAZAWA, M., KATO, K. and KITAMURA, K. (1997). Expression of a novel aristaless related homeobox gene 'Arx' in the vertebrate telencephalon, diencephalon and floor plate. Mech Dev 65: 99-109.

MIYABAYASHI, K., KATOH-FUKUI, Y., OGAWA, H., BABA, T., SHIMA, Y., SUGIYAMA N., KITAMURA, K. and MOROHASHI, K. (2013). Aristaless related homeobox gene, Arx, is implicated in mouse fetal Leydig cell differentiation possibly through expressing in the progenitor cells. PLoS One 8: e68050.

NAPOLITANO, T., AVOLIO, F., COURTNEY, M., VIEIRA, A., DRUELLE, N., BENOTHMAN, N., HADZIC, B., NAVARRO, S. and COLLOMBAT, P. (2015). Pax4 acts as a key player in pancreas development and plasticity. Semin Cell Dev Biol 44: 107-114.

NISHIYAMA, A., YAMAGUCHI, L. and NAKANISHI, M. (2016). Regulation of maintenance DNA methylation via histone ubiquitylation. J Biochem 159: 9-15.

OHIRA, R., ZHANG, Y.H., GUO, W., DIPPLE, K., SHIH, S.L., DOERR, J., HUANG, B.L., FU, L.J., ABU-KHALIL, A., GESCHWIND, D. et al., (2002). Human ARX gene: genomic characterization and expression. Mol Genet Metab 77: 179-188.

OLIVETTI, P.R. and NOEBELS, J.L. (2012). Interneuron, interrupted: molecular pathogenesis of ARX mutations and X-linked infantile spasms. Curr Opin Neurobiol 22: 859-865.

PAPIZAN, J.B., SINGER, R.A., TSCHEN, S.I., DHAWAN, S., FRIEL, J.M., HIPKENS, S.B., MAGNUSON, M.A., BHUSHAN, A. and SUSSEL, L. (2011). Nkx2.2 repressor complex regulates islet beta-cell specification and prevents beta-to-alpha-cell reprogramming. Genes Dev 25: 2291-2305.

PEARL, E.J. and HORB, M.E. (2008). Promoting ectopic pancreatic fates: pancreas development and future diabetes therapies. Clin Genet 74: 316-324.

REFAAT, B. (2014). Role of activins in embryo implantation and diagnosis of ectopic pregnancy: a review. Reprod Biol Endocrinol 12: 116.

REZANIA, A., RIEDEL, M.J., WIDEMAN, R.D., KARANU, F., AO, Z., WARNOCK, G.L. and KIEFFER, T.J. (2011). Production of functional glucagon-secreting alpha-cells from human embryonic stem cells. Diabetes 60: 239-247.

RIEDEL, M.J., ASADI, A., WANG, R., AO, Z., WARNOCK, G.L. and KIEFFER, T.J. (2012). Immunohistochemical characterisation of cells co-producing insulin and glucagon in the developing human pancreas. Diabetologia 55: 372-381.

RUKSTALIS, J.M. and HABENER, J.F. (2009). Neurogenin3: a master regulator of pancreatic islet differentiation and regeneration. Islets 1: 177-184.

SAHIN, F. and SLADEK, T.L. (2010). E2F-1 binding affinity for $p R b$ is not the only determinant of the E2F-1 activity. Int J Biol Sci 6: 382-395.

SANDER, M., SUSSEL, L., CONNERS, J., SCHEEL, D., KALAMARAS, J., DELA CRUZ, F., SCHWITZGEBEL, V., HAYES-JORDAN, A. and GERMAN, M. (2000). Homeobox gene Nkx6.1 lies downstream of Nkx2.2 in the major pathway of betacell formation in the pancreas. Development 127: 5533-5540.

SCHAFFER, A.E., TAYLOR, B.L., BENTHUYSEN, J.R., LIU, J., THOREL, F., YUAN W., JIAO, Y., KAESTNER, K.H., HERRERA, P.L., MAGNUSON, M.A. et al., (2013). Nkx6.1 controls a gene regulatory network required for establishing and maintaining pancreatic Beta cell identity. PLoS Genet 9: e1003274.

SHOUBRIDGE, C., FULLSTON, T. and GECZ, J. (2010). ARX spectrum disorders: making inroads into the molecular pathology. Hum Mutat 31: 889-900.

SOSA-PINEDA, B., CHOWDHURY, K., TORRES, M., OLIVER, G. and GRUSS, P. (1997). The Pax4 gene is essential for differentiation of insulin-producing beta cells in the mammalian pancreas. Nature 386: 399-402.

STROMME, P., MANGELSDORF, M.E., SCHEFFER, I.E. and GECZ, J. (2002a). Infantile spasms, dystonia, and other $X$-linked phenotypes caused by mutations in Aristaless related homeobox gene, ARX. Brain Dev 24: 266-268.

STROMME, P., MANGELSDORF, M.E., SHAW, M.A., LOWER, K.M., LEWIS, S.M., BRUYERE, H., LUTCHERATH, V., GEDEON, A.K., WALLACE, R.H., SCHEFFER, I.E. et al., (2002b). Mutations in the human ortholog of Aristaless cause X-linked mental retardation and epilepsy. Nat Genet 30: 441-445.

SUGIYAMA, T., BENITEZ, C.M., GHODASARA, A., LIU, L., MCLEAN, G.W., LEE, J., BLAUWKAMP, T.A., NUSSE, R., WRIGHT, C.V., GU, G. et al., (2013). Reconstituting pancreas development from purified progenitor cells reveals genes essential for islet differentiation. Proc Natl Acad Sci USA 110: 12691-12696.

SUISSA, Y., MAGENHEIM, J., STOLOVICH-RAIN, M., HIJA, A., COLLOMBAT, P., MANSOURI, A., SUSSEL, L., SOSA-PINEDA, B., MCCRACKEN, K., WELLS, J.M. et al., (2013). Gastrin: a distinct fate of neurogenin3 positive progenitor cells in the embryonic pancreas. PLoS One 8: e70397.

SUN, B., WINGATE, H., SWISHER, S.G., KEYOMARSI, K. and HUNT, K.K. (2010). Absence of $\mathrm{pRb}$ facilitates E2F1-induced apoptosis in breast cancer cells. Cell Cycle 9: 1122-1130.

SUSSEL, L., KALAMARAS, J., HARTIGAN-O'CONNOR, D.J., MENESES, J.J., PEDERSEN, R.A., RUBENSTEIN, J.L. and GERMAN, M.S. (1998). Mice lacking the homeodomain transcription factor Nkx2.2 have diabetes due to arrested differentiation of pancreatic beta cells. Development 125: 2213-2221.

TERRY, N.A., LEE, R.A., WALP, E.R., KAESTNER, K.H. and LEE MAY, C. (2015) Dysgenesis of enteroendocrine cells in Aristaless-Related Homeobox polyalanine expansion mutations. J Pediatr Gastroenterol Nutr 60: 192-199.

THOREL, F., DAMOND, N., CHERA, S., WIEDERKEHR, A., THORENS, B., MEDA, P., WOLLHEIM, C.B. and HERRERA, P.L. (2011). Normal glucagon signaling and beta-cell function after near-total alpha-cell ablation in adult mice. Diabetes 60: $2872-2882$

UDAYAKUMAR, T., SHAREEF, M.M., DIAZ, D.A., AHMED, M.M. and POLLACK, A (2010). The E2F1/Rb and p53/MDM2 pathways in DNA repair and apoptosis: understanding the crosstalk to develop novel strategies for prostate cancer radiotherapy. Semin Radiat Oncol 20: 258-266.

VAN DER MEULEN, T. and HUISING, M.O. (2015). Role of transcription factors in the transdifferentiation of pancreatic islet cells. J Mol Endocrinol 54: R103-R117.

WILCOX, C.L., TERRY, N.A. and MAY, C.L. (2013a). Arx polyalanine expansion in mice leads to reduced pancreatic alpha-cell specification and increased alpha-cell death. PLoS One 8: e78741. 
WILCOX, C.L., TERRY, N.A., WALP, E.R., LEE, R.A. and MAY, C.L. (2013b). Pancreatic alpha-cell specific deletion of mouse Arx leads to alpha-cell identity loss. PLoS One 8: e66214.

WU, Z. and YU, Q. (2009). E2F1-mediated apoptosis as a target of cancer therapy. Curr Mol Pharmacol 2: 149-160.

XU, S., HAYASHI, Y., TAKAGISHI, Y., ITOH, M. and MURATA, Y. (2013). Aristalessrelated homeobox plays a key role in hyperplasia of the pancreas islet alpha-like cells in mice deficient in proglucagon-derived peptides. PLoS One 8: e64415.
YOSHIHARA, S., OMICHI, K., YANAZAWA, M., KITAMURA, K. and YOSHIHARA $Y$. (2005). Arx homeobox gene is essential for development of mouse olfactory system. Development 132: 751-762.

YU, H., PASK, A.J., HU, Y., SHAW, G. and RENFREE, M.B. (2014). ARX/Arx is expressed in germ cells during spermatogenesis in both marsupial and mouse. Reproduction 147: 279-289.

ZHUANG, S., ZHANG, Q., ZHUANG, T., EVANS, S.M., LIANG, X. and SUN, Y. (2013). Expression of Isl1 during mouse development. Gene Expr Patterns 13: 407-412. 


\section{Further Related Reading, published previously in the Int. J. Dev. Biol.}

The triumvirate of beta-cell regeneration: solutions and bottlenecks to curing diabetes Sumeet P. Singh and Nikolay Ninov Int. J. Dev. Biol. (2018) 62: 453-464 https://doi.org/10.1387/ijdb.180067nn

Induction of differentiation of undifferentiated cells into pancreatic beta cells in vertebrates Masaki Hosoya, Yuya Kunisada, Akira Kurisaki and Makoto Asashima Int. J. Dev. Biol. (2012) 56: 313-323

https://doi.org/10.1387/ijdb.123522mh

Characterization of mouse embryonic stem cell differentiation into the pancreatic lineage in vitro by transcriptional profiling, quantitative RT-PCR and immunocytochemistry

Alexandra Rolletschek, Insa S. Schroeder, Herbert Schulz, Oliver Hummel, Norbert Huebner and Anna M. Wobus

Int. J. Dev. Biol. (2010) 54: 41-54

https://doi.org/10.1387/ijdb.082694ar

Pdx1-transfected adipose tissue-derived stem cells differentiate into insulin-producing cells in vivo and reduce hyperglycemia in diabetic mice

Hiromitsu Kajiyama, Tatsuo S. Hamazaki, Makoto Tokuhara, Shinji Masui, Koji Okabayashi, Kiyoshi Ohnuma, Shigeharu Yabe, Kazuki Yasuda, Shoichi Ishiura, Hitoshi Okochi and Makoto Asashima

Int. J. Dev. Biol. (2010) 54: 699-705

https://doi.org/10.1387/ijdb.092953hk

Mouse ES cells over-expressing the transcription factor NeuroD1 show increased differentiation towards endocrine lineages and insulin-expressing cells

Mélanie Marchand, Insa S. Schroeder, Suzy Markossian, Anouchka Skoudy, Didier Nègre, François-Loïc Cosset, Paco Real, Christian Kaiser, Anna M. Wobus and Pierre Savatier Int. J. Dev. Biol. (2009) 53: 569-578

https://doi.org/10.1387/ijdb.092856mm

Genes controlling pancreas ontogeny

Claire Bonal and Pedro L. Herrera

Int. J. Dev. Biol. (2008) 52: 823-835

https://doi.org/10.1387/ijdb.072444cbRupnik and Anna M. Wobus

Int. J. Dev. Biol. (2004) 48: 1095-1104

http://www.intjdevbiol.com/web/paper/041904pb
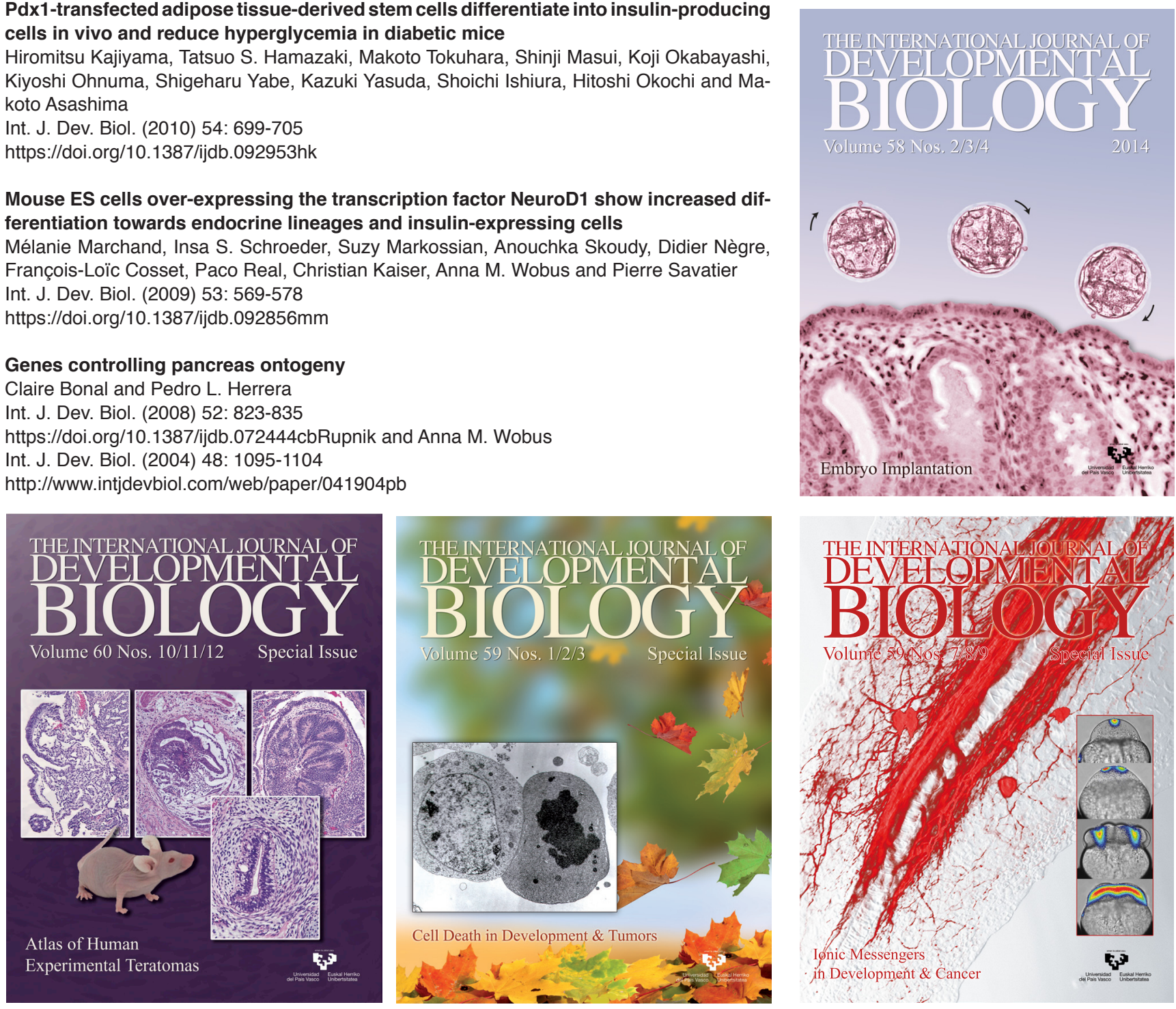